\title{
Congenital isolated transverse colon dilatation
}

\author{
Mehran Hiradfar, ${ }^{1}$ Reza Shojaeian, ${ }^{1}$ Ali Alamdaran ${ }^{2}$
}

'Department of Pediatric Surgery, Mashhad University of Medical Sciences, Mashhad, Islamic Republic of Iran ${ }^{2}$ Department of Pediatric Radiology, Mashhad University of Medical Sciences, Mashhad Islamic Republic of Iran

\section{Correspondence to}

Dr Reza Shojaeian, drshojaeian@ymail.com

Accepted 18 December 2015

\section{DESCRIPTION}

Gastrointestinal obstructive symptoms are common in the neonatal period and a contrast enema is considered an early paraclinical assessment with diagnostic and sometimes therapeutic value. Colonic dilation may be seen in Hirschsprung disease or other neurointestinal dysplasia, small left colon syndrome, meconial diseases, congenital rectal stenosis, incomplete rectal atresia, congenital pouch colon (CPC), splenic flexure stenosis and necrotising enterocolitis, etc. ${ }^{1}$ However, imaging findings may be confusing due to rare anatomical abnormalities especially in the neonatal period. ${ }^{2}$ Our case was a 2-month-old infant with a lifetime history of abdominal distention and severe constipation, who was referred to the paediatric surgery ward, suspected of having gastrointestinal perforation during a diagnostic contrast enema (figure 1). A football colon, which is a huge dilated segment of colon, may be encountered in infancy, classically in such rare diseases as CPC or segmental colon dilation. ${ }^{3}$ Radiological imaging may reveal contrast material throughout the abdominal cavity, with sounds of free hollow viscous perforation, but looking carefully, a huge colon and scattered intraluminal contrast materials that occupy the entire abdominal cavity will be distinguished. An unused distal colon and shoulder sign indicate local involvement of the gastrointestinal tract. Our patient underwent laparotomy and resection of the involved segment of the colon and double barrel colostomy, and multiple intestinal biopsies were carried out. Histological examination of the resected bowel showed normal colonic tissue and normal ganglion cells among all the tissue specimens, which suggested congenital megacolon (figure 2). Delayed colostomy closure was performed after 2 months with the final diagnosis of

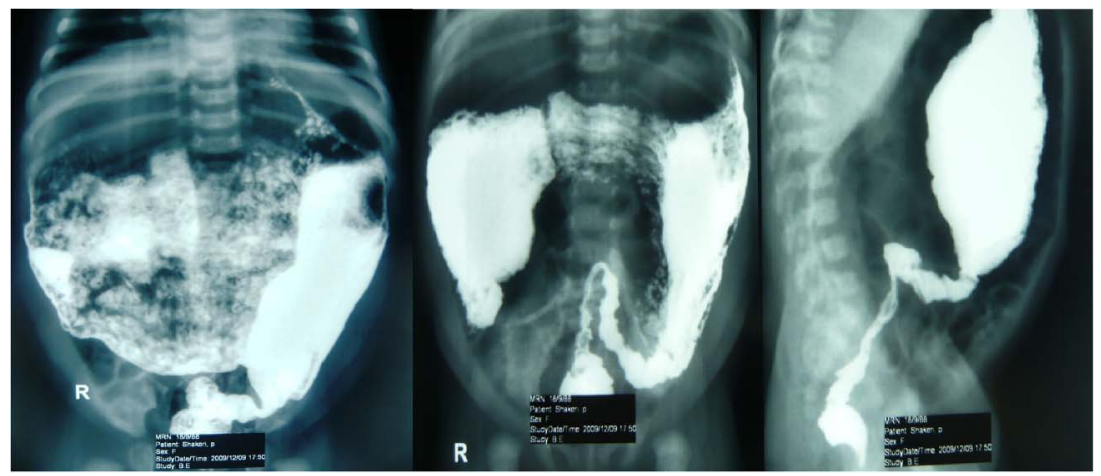

Figure 1 Scattered image of barium enema in the abdominal cavity mimicking free spillage of barium in the abdominal cavity (left). Ectasia of the transverse colon (middle and right).

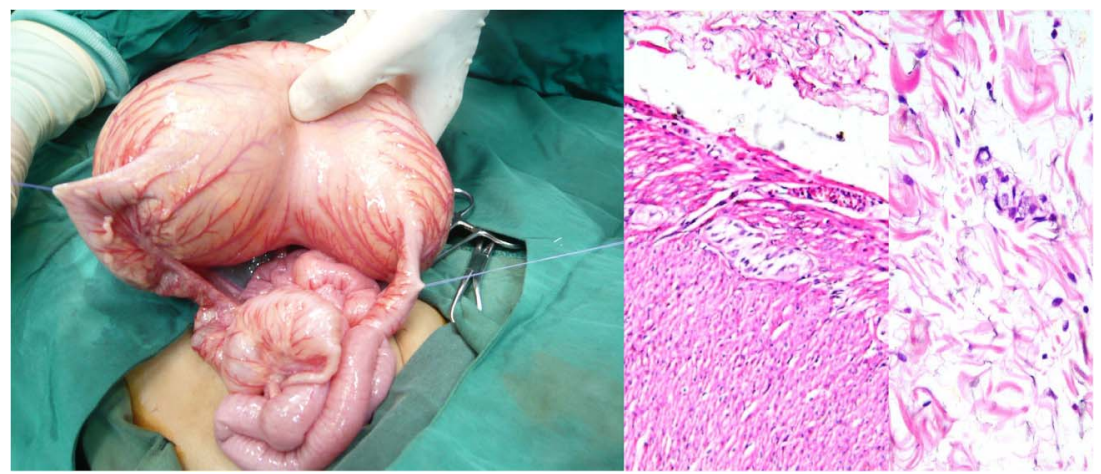

Figure 2 Intraoperative findings: A huge transverse colon ectasia (transverse football colon). Microscopic findings: Presence of ganglion cells in the submucous (Meissner) and myenteric (Auerbach) plexuses (right). 
congenital segmental megacolon. The postoperative period was uneventful and the patient did well during 4 years of follow-up.

\section{Learning points}

- A huge football colon may show a confusing image in contrast study.

- A proximal shoulder sign is a useful image characteristic of congenital pouch colon or segmental colon ectasia.

- Segmental colon dilation may be seen as a congenital anatomic abnormality even in the absence of a neurointestinal disorder.
Acknowledgements The authors thank the Endoscopic and Minimally Invasive Surgery Research Center, Ghaem Hospital, Faculty of Medicine, Mashhad University of Medical Sciences, Mashhad, Iran.

Contributors MH was the surgeon in charge of the patient, RS designed the manuscript and AA was the consultant radiologist.

Competing interests None declared.

Patient consent Obtained.

Provenance and peer review Not commissioned; externally peer reviewed.

\section{REFERENCES}

1 Frager D, Rovno HDS, Baer JW, et al. Prospective evaluation of colonic obstruction with computed tomography. Abdom Imaging 1998;23:141-6.

2 Taipale P, Rovamo L, Hiilesmaa V. First trimester diagnosis of imperforate anus. Ultrasound Obstet Gynecol 2005;25:187-8.

3 Chadha R, Gupta S, Tanwar US, et al. Congenital pouch colon associated with segmental dilatation of the colon. J Pediatr Surg 2001;36:1593-5.

Copyright 2016 BMJ Publishing Group. All rights reserved. For permission to reuse any of this content visit http://group.bmj.com/group/rights-licensing/permissions.

BMJ Case Report Fellows may re-use this article for personal use and teaching without any further permission.

Become a Fellow of BMJ Case Reports today and you can:

- Submit as many cases as you like

- Enjoy fast sympathetic peer review and rapid publication of accepted articles

- Access all the published articles

- Re-use any of the published material for personal use and teaching without further permission

For information on Institutional Fellowships contact consortiasales@bmjgroup.com

Visit casereports.bmj.com for more articles like this and to become a Fellow 